\title{
Economic Efficiency Estimation of Intangible Assets Use
}

Vetoshkina E.Yu. ${ }^{\mathrm{a}}$

Tukhvatullin R.Sh. ${ }^{b}$

ab Kazan Federal University, Institute of Management, Economics and Finance, Kazan, 420008, Russia

\section{Doi:10.5901/mjss.2015.v6n1s3p440}

\section{Abstract}

The article comprises a set of theoretical and methodological statements and practical suggestions about the specific ways of estimation of intangible assets. The problems of the intangible assets development process management and their further application effectiveness deserve the most serious attention However, the problem of the intangible assets development process management and their further application effectiveness is not illustrated enough.

Keywords: intangible assets, estimation, economic efficiency.

\section{Introduction}

There is no doubt that modern production cannot function effectively without sophisticated technological developments, the results of innovative activity and scientific-applied researches. The lag in the latest developments, high-efficiency technologies, and application of knowledge-intensive production leads to stagnation of the productive forces of society. However, even possessing the significant scientific developments or progressive ideas, the company does not always introduce them into production or mastering of the advanced technologies. The main reason - is in the wrong setting of priorities, inefficient methods of use and management of the research work results carried out in the companies, underestimation of the motivational mechanism influence on engineering manpower professional activity. Therefore, the problems of the intangible assets development process management and their further application effectiveness deserve the most serious attention. In addition there is the problem of fair disclosure in the financial statements of companies. Aletkin P.A. notes, that in case with Russia companies it is not clear if the disclosure of information under IFRS will help investors in getting high quality data about financial position and financial results of the companies (Aletkin P.A., 2014).

Note that the knowledge-intensive production can reach success at the market only under the certain conditions:

1) a clear understanding of the demand scope for innovation among potential consumers, its economic expression of advantages over existing analogues;

2) competent distribution of roles and functions of human resource personnel meeting the requirements of high professionalism, working efficiency, final result orientation, etc.

3) formalized approach exclusion in the formation of the management structure, a singular focus on speed and flexibility in management decision-making;

4) monitoring system establishment for the effectiveness of R\&D results implementation into industrial production;

5) creation of an analytical indicators system allowing to assess the profitability of generated intangible assets, their contribution into the final results of financial and economic activity of the organization.

\section{Theory}

The task of the technical and economic importance of inventions determining has been formulated back in the middle of the last century due to the necessity of the complex "science-production" management (Anne Marie Knott, 2003). Questions of evaluation of intangible assets are presented in the most interesting works of the following scholars: Anne Wyatt (2005), Erik Brynjolfsson (2002), Gema Pastor-Agustín (2011), Lie Dharma (2009), Richard N. Cooper (2010). However, currently there is not a single methodological approach to the significance of inventions and approved methodologies evaluation. It is determined by several reasons:

1) objects of intangible assets are specific accounting objects; they are heterogeneous in their composition, the 
nature of the use, the degree of impact on the financial and economic results of the company;

2) the share of intangible assets in the aggregate of all assets of the company may be insignificant (but it should be noted that this fact is often a consequence of the non-rational organization of accounting, when intangible assets are ignored, and the costs of their creation (acquisition) are charged to the income statement simultaneously, without capitalization as an asset);

3) underestimation of the intangible objects role by the heads of the companies traditionally oriented to the improvement of material-mass base;

4) the absence until the present time of a unified system of economic indicators able to comprehensively characterize the commercial use of intangible assets.

Nevertheless, one cannot deny the fact of high yields of individual intangible assets. Thus, if the average annual growth rate of world industrial production comprises about 2.5-3\%, then the global trade of licenses for use of industrial property and technology is growing at a rate as high as $12 \%$ per year. At the same time, it must be emphasized that investments in intellectual property objects are the most risky sector of economy (Valeria Gattai, 2010).

Most companies are interested in the efficiency of investments into the creation of certain intangible assets, that is - income per unit of investment (Kulikova L.I., Ivanovskaya A.V., 2014). Note that the income from the use of intangible assets is the difference over a certain period of time between cash receipts and cash payments received by the rights holder for the right to use objects. Benefit from the use of intangible assets is determined on the basis of direct comparison of the value, risk, and time of receipt of the cash flow from the use of intangible assets with the value, risk and time of receipt of the cash flow which the right holder would have received not using these facilities. This approach can be implemented by discounting or capitalization of cash flows from the use of intellectual property. If the cash flows from the use of intangible assets objects in equal intervals of time are not the same, then the amount of value is determined by discounting of the future cash flows. For us, this approach is interesting for some options, which are possible here. Thus, this method lies in the basis for determining the benefits in the profit, which has the owner of intangible assets. Sufficient degree of accuracy is the prerequisite of the advantage in profits analysis fulfillment which means the amount of additional revenue obtained due to the possession of the rights to the property and its use in the exercise of economic activity (detected when compared to analogue). Under the advantage of profit the additional net profit (after tax) is construed, which is obtained with each item of product using the intangible assets. This advantage can be achieved by improving the quality of products, or in addition to this factor, by increasing the popularity of the company (for example, increasing the knowledge of the trademark). The advantage of profit appears:

1) as compared to the company, which manufactures products similar to the products of the company under consideration;

2) in relation to the present company, manufacturing these products before and after the use of intangible assets. Annual profit advantage expressed in monetary terms is reduced to the present value taking into account the expected period of its receipt:

$\mathrm{C}=\sum V_{t} * \Delta P_{t} * K$

where

$\mathrm{C}$ - profit advantage;

$\mathrm{Vt}$ - volume of products manufactured using the intangible asset in the t-year;

$\Delta \mathrm{Pt}$ - the advantage of profits expected to gain from the use of an intangible asset in the t-year;

$\mathrm{K}$ - the discount factor in the t-year.

In our opinion, this method is of particular interest because it is often this approach is used to estimate the value of inventions. This annual advantage in profit is discounted based on the expected period of its receipt. However, when using this method it is necessary to take into account that the additional revenue can be obtained just in case of an increase in demand for the company's products due to other factors.

As a rule, in the practice of companies there are situations where it is difficult to assess the potential net income attributable to the object of intangible assets. Companies produce a large range of products, and it is a complex task to determine income, which is brought by a particular type of product and what's more - the object of intellectual property used to it. In this regard, it is proposed to use the method of the profit separating attributable to the object of intangible assets.

Wherein the following steps are performed:

1) the expected remaining useful life of the asset is determined;

2) the income derived by an enterprise from the products using the intangible asset is forecasted;

3) the cash flow as the income generated by the intangible assets is forecasted (by allocating of an appropriate share); 
4) the discount rate is determined;

5) the total present value of future income is calculated;

Note that the share of profits attributable to an object of intellectual property depends on many factors, among which are the following: the degree of legal protection, the presence of existing similar ones already used in production, including competing companies, the profitability of the industry as a whole, etc. The share of profit is determined, usually by experts and by some estimates, and may comprise $10-35 \%$ of the total profit from the use of the material object of technology (products), in which (or in part thereof) the intangible assets object is embodied. The disadvantage of the above method is that the data for the calculations is determined mainly by experts, that brings subjectivity in the analysis.

The need to record the risks in the analysis of the intangible assets effectiveness causes no doubt, since the implementation of the results of intellectual activity is associated with a list of external risks (associated with market conditions) and internal ones (peculiar only to this project). Significantly higher is the project risk with incomplete implementation phase or even with the unfinished stage of research and development activities focused on the promotion of new products and technologies. In developing of such projects many decisions are made on an intuition level, since in most cases the required information is missing. Note that in terms of political and economic instability, the analysis of such risks is of particular importance.

\section{Results}

The world practice of financial management uses different methods of own risks analysis. The most common ones are: the method of the discount rate adjusting (for approximate calculations), the method of certainty equivalents (certainty coefficient), analysis of performance criteria sensitivity, the method of scenarios, the analysis of probability distributions of cash flows and other methods. In general, the following should be noted that one of the tasks of analytical work in the field of the intangible assets effectiveness assessment is to determine the most effective option of the object use. At the same time, the most efficient use is construed as the use of the object by the actually existing user, who is physically possible, reasonably justified, legitimate and feasible from a financial point of view, the positive effect of which is estimated as the maximum.

One of the distinguishing features of intangible assets is the ability to both in-process application of intangible assets as a resource potential of the company, and their commercial use. It is therefore proposed to divide the entire set of analytical indicators into two groups. The first group characterizes the efficiency of intra-industrial use of intangible assets, the second is the effectiveness of their commercial application.

Table 1 represents the parameters included in the first group.

Table 1. Indexes of intra-productive use of intangible assets effectiveness

\begin{tabular}{|c|c|c|}
\hline № & Indicators & Comments \\
\hline 1 & Depreciation coefficient & $\begin{array}{l}\text { Suitability of this coefficient application for the purposes of analysis is questionable, as the physical } \\
\text { depreciation is not characteristic for intangible assets. Though, note that this type of assets is } \\
\text { exposed to a considerable moral depreciation, and it is impossible to determine its period with the } \\
\text { sufficient degree of reliability. }\end{array}$ \\
\hline 2 & $\begin{array}{l}\text { Coefficient of qualification, renewal, } \\
\text { acquisitions and disposals }\end{array}$ & $\begin{array}{l}\text { Economic purpose is characterization of the movement process and the renewal degree of thee } \\
\text { company's innovative component, the level of its compliance with the modern conditions }\end{array}$ \\
\hline 3 & $\begin{array}{l}\text { The level of intra-productive returns } \\
\text { from intangible assets }\end{array}$ & $\begin{array}{l}\text { Is determines judging from the gross income of the company gained from the sales of its products } \\
\text { (works, services) basing on or with application of the intangible assets, per the unit of the average } \\
\text { price of the indicated assets for the calculated period of time. The comparison base must be added } \\
\text { with the data of the level of returns from intangible assets of the competitor companies, the best } \\
\text { achievements from the data of the knowledge-intensive companies (reference value) }\end{array}$ \\
\hline 4 & $\begin{array}{l}\text { Coefficient of extensive use of } \\
\text { intangible assets }\end{array}$ & $\begin{array}{l}\text { Is calculated as the product of two indicators: the coefficient of extensiveness of intangible assets } \\
\text { use in the area (calculated as the ration between the intangible assets value used in the company } \\
\text { and the total value of produced R\&D costs for this period) and the coefficient of intangible assets use } \\
\text { by the time of the company operation (calculated as the ratio between the working and calendar time } \\
\text { fund in the company). }\end{array}$ \\
\hline 5 & $\begin{array}{l}\text { Revenue share from the use of } \\
\text { intangible assets in manufacturing of } \\
\text { products (works, services) }\end{array}$ & $\begin{array}{l}\text { This indicator is difficult for calculation. As a rule, expert-statistical method is used for its calculation } \\
\text { (we have dealt on this earlier). }\end{array}$ \\
\hline 6 & $\begin{array}{l}\text { Pay-back period of investments into } \\
\text { intangible assets }\end{array}$ & $\begin{array}{l}\text { In modern conditions of industrial enterprises economic management this indicator on the average } \\
\text { may be twice as low as compared to the similar one by the permanent assets. This is explained by: } \\
\text { firstly, by the high intensity of innovation activity, and thus, quick renovation of intangible assets; } \\
\text { secondly, by the permanent costs for support and development of scientific-innovational potential; } \\
\text { thirdly, by the high risk of investing into the intangible assets due to not sufficiently efficient intra- } \\
\text { production use or commercial (market) failure. }\end{array}$ \\
\hline
\end{tabular}


The second group of indicators characterizing the efficiency of commercial use of intangible assets consists of the following factors:

1) The level of commercial returns from the intangible assets, which is defined as the ratio of income from the commercial use of the intangible asset and their average value for the period.

2) The return on intangible assets, calculated as the ratio of the balance sheet profit of the adopted version of the intangible asset to the total amount of the costs required for the creation and use of the intangible asset.

3) Readiness of intangible assets of internal manufacturing for use as commercial application. Studies show that more than half of all of intangible assets used in the production are created directly by the companies. Corresponding coefficient of intangible asset availability for commercial use $\left(K_{r}\right)$ is calculated by the formula:

$\mathrm{K}_{r}=\frac{\sum_{i=1}^{\mathrm{n}} \mathrm{C}_{\mathrm{n}}}{\sum_{i=1}^{n} \mathrm{C}_{n}+\sum_{j=1}^{m} C_{m}}$

where

$\mathrm{C}_{n}$ - the relevant elements of the costs of the i-th object of intangible assets;

$\mathrm{n}$ - is the number of intangible assets prepared for commercial sale in the reporting period;

$\mathrm{C}_{\mathrm{m}}$ - relevant elements of the costs of the j-th object of intangible assets;

$\mathrm{m}$ - the number of intangible assets not ready for commercial sale created by the company in the reporting period.

Exemplary allowable $\mathrm{K}_{\mathrm{r}}$ values lie within the range of 0.7 to 0.9 . By increasing the upper value of the specified index the backlogs of intangible assets are reduced to a dangerously small value (less than 10\%), which is usually insufficient for the effective implementation of innovation activity in the current reporting period. If the lower value is less than 0.7 - then the indicator of the backlogs for intangible assets is comparable with the index of objects prepared for the commercial use, indicating the "freezing" of working capital in innovation activity.

\section{Conclusions}

Thus, we see that majority of the indicators used for assessment of innovation organization effectiveness is determined by a statistical expertize, which introduces an element of subjectivity in the analysis conducted in this way. The greatest effect is achieved by continuous monitoring of the dynamics of the above factors and their values as compared with the similar indicators of the competitor companies.

\section{References}

Aletkin P. A. International Financial Reporting Standards Implementation into the Russian Accounting System. Mediterranean Journal of Social Sciences, 2014, Vol.5, No 24, November 24, pp. 33-38

Anne Wyatt Accounting Recognition of Intangible Assets: Theory and Evidence on Economic Determinants The Accounting Review, Vol. 80, 3 (Jul., 2005), pp. 967-1003

Anne Marie Knott, David J. Bryce, Hart E. Posen On the Strategic Accumulation of Intangible Assets Organization Science, Vol. 14, 2 (Mar. - Apr., 2003), pp. 192-207

Erik Brynjolfsson, Lorin M. Hitt, Shinkyu Yang Intangible Assets: Computers and Organizational Capital Brookings Papers on Economic Activity, Vol. 2002, 1 (2002), pp. 137-181

Gema Pastor-Agustín, Marisa Ramírez-Alesón and Manuel Espìtia-Escuer. Complementary Assets and Investment Decisions. Emerging Markets Finance \& Trade Vol. 47, Supplement 5: Capital Markets, Trade Openness, and Productivity in Emerging Economies (November-December 2011), pp. 25-39

Grace T. R. Lin, Jerry Y. H. Tang Appraising Intangible Assets from the Viewpoint of Value Drivers Journal of Business Ethics, Vol. 88, No. 4 (Sep., 2009), pp. 679-689

Kulikova L.I., Ivanovskaya A.V., Antonova N.V. Efficiency Analysis of Taking out Real Estate Loans for Profit-Making Organizations. Mediterranean Journal of Social Sciences, 2014, Vol.5, No 24, November 24, pp. 70-75

Kulikova L.I., Goshunova A.V. Measuring efficiency of professional football club in contemporary researches. World Applied Sciences Journal, 2013; 25(2): 247-257

Lie Dharma Putra Accounting For Intangible Assets [IAS 38] With Case Example http://accounting-financial-tax.com/2009/03/accountingfor-intangible-assets-ias-38-with-case-examples

Richard N. Cooper Review: From Poverty to Prosperity: Intangible Assets, Hidden Liabilities, and the Lasting Triumph Over Scarcity by Arnold King, Nick Schulz. Foreign Affairs, Vol. 89, 3 (May/June 2010), p. 136

Valeria Gattai Firm's intangible assets and multinational activity: Full versus shared ownership The Journal of International Trade \& Economic Development, Volume 19, Issue 4, December 2010, pages 553-589.

Vetoshkina E.Yu., Tukhvatullin R.Sh. The Problem of Accounting for the Costs Incurred After the Initial Recognition of an Intangible Asset. Mediterranean Journal of Social Sciences, 2014,Vol.5, No 24, November 24, pp. 52-56. 